\title{
The Constrained Self-Voice of the Female_-On Fiona and Marian in "The Bear Came Over the Mountain”
}

\author{
PU Ya-zhu \\ Officers’ College of CAPF, Chengdu, P. R. China
}

\begin{abstract}
Fiona and Marian, the two female roles of Alice Munro’s short story “The Bear Came Over the Mountain” always catch little attention of the readers who instead pay more attention to the male protagonist Grant. In actuality, the two female roles share a common point which needs readers and critics to carefully analyze and re-evaluate. That is both female roles' self-voice which is constrained against the man-center traditional perspective. This essay just aims to reanalyze and elaborate the two female roles by using the methods and theories of feminist criticism in order to discover and release the constrained self-voice of the female.
\end{abstract}

Keywords: Fiona, Marian, “The Bear Came Over the Mountain”, constrained self-voice of the female, feminist criticism

Alice Munro, as one of the most successful female short story writers, is good at catching the flashes of daily life by using her vivid, soft, and graceful words. "The Bear Came Over the Mountain” is just this case. This short story is collected in her book of short stories titled Hateship, Friendship, Courtship, Loveship, Marriage. The reason that this short story catches a lot of people's attention is not only because it well represents Munro's writing style but it has been adapted to the film "Away From Her" starred by elite actors and actresses.

Through “The Bear Came Over the Mountain”, Munro tells readers a sad and moving love story happening to an old couple. Fiona and Grant are close couple having married for over 40 years. But their life has undergone a change since Fiona got Alzheimer's disease and Grant must finally place her in an institution. To Grant's horror however, he watches Fiona establishes a romantic bond with another demented patient, Aubrey, whose appearance, behavior, and education are nothing like Grant's. At first, Grant resents the threat, then he gradually accepts Fiona's need. While Fiona's situation is aggravated after Aubrey was brought home by his wife Marian, Grant awkwardly tries to encourage Marian to send Aubrey back or at least to allow regular visits. However, Fiona improves anyway, her disease having rapidly eradicated the memory of Aubrey, while at this time, Grant and Marian are exchanging telephone messages about the possibility of a date.

It's no doubt that Grant is the absolute protagonist and hero, from whom readers can tell a kind of deep affection towards his wife Fiona and can be deeply moved by the strong and insistent love. It seems that Munro established Grant with a lot of fine characteristics: perseverance, sincere affection towards Fiona, and even making self-sacrifice. Indeed, Grant consistently loves Fiona, "He wanted never to be away from her. She had the

PU Ya-zhu, MA, Lecturer, Department of Basic Courses, Officers’ College of CAPF, Chengdu, P. R. China. 
spark of life" (Munro, 1999). However when the majority of people pay more attention to Grant from a perspective of sympathy and admiration, I put my eyes on the two female roles in this fiction—Fiona and Marian. They are the two heroines with totally different characteristics in Munro's writing. Fiona always keeps her beauty and grace. "She was a tall, narrow-shouldered woman, seventy years old but still upright and trim, with long legs and long feet, delicate wrists and ankles, and tiny, almost comical-looking ears" (Munro, 1999). While in both Munro and Grant's eyes, Marian is far less beautiful than Fiona. "Her hair was short, curly, artificially, reddened. She had blue eyes-a lighter blue than Fiona's—a flat robin's-egg or turquoise blue, slanted by a slight puffiness. And a good many wrinkles, made more noticeable by a walnut-stain makeup” (Munro, 1999). Even if like this, the two women do share the common thing, that is, to a certain extent, they lose their own voice to define and elaborate themselves. All what the readers know about them is from Grant's eyes and his own mental activities. That's also why Grant can strengthen his role as the absolute hero in readers' heart.

However, here I want to step forward to say something for the two female roles: Fiona and Marian. No matter how readers adore Fiona's beauty and grace, also sympathize with her misfortune and how they hate Marian's toughness and coldness, in actuality, both women should deserve our sympathy and understanding. This short story, written by a woman, should particularly be re-read and evaluated because a thousand readers can read out a thousand Hamlets on the one hand; Munro's peculiar perspective to tell the story also needs us to pay attention to on the other. So I try to re-analyze and deconstruct the two female roles by using the methods of feminist critics.

To begin with the analysis, I think it's necessary to bring about a term first: "gynocriticism". This term, named by Elaine Showalter, “involves women reading about women's texts and constructing a largely sympathetic discourse about this body of work” (Green \& LeBihan, 1996, p. 239). The deconstruction of the two female roles in Munro's this short story just applies to this method. Showalter explains: "The program of gynocritics is to construct a female framework for the analysis of women's literature, to develop new models based on the study of female experiences, rather than to adapt male models and theories” (Showalter, 1986, p. 131). Since that, as an individual reader, I have my own thoughts about the roles in this short story; besides, as a woman reader, I insist on that it's reasonable to pay more attention to the two female roles from a brand new point of view, breaking out the traditional even the male model of explaining and defining Fiona and Marian with the reason that the need for gynocriticism

is based on the idea that [...] but they have also been systematically misread, or read according to the expectations and values of the wrong gender. The argument of 'gynocriticism' is not only that women write about different subjects to men, but they also read and criticize them differently. (Green \& LeBihan, 1996, p. 239)

Tracing back to the history of feminism development, "the period of dramatic change in the influence of feminism that took place in the late 1960s and after has therefore become known as the 'Second Wave'” (Green \& LeBihan, 1996, p. 230). During this period, feminism literary criticism had transferred from the age of Virginia Woolf who emphasized women's economic independence and the breaking out of the restriction towards women writing in her "Shakespeare's Sister: From a Room of One’s Own” to that represented by Sandra M. Gilbert and Susan Gubar with "Tradition and the Female Talent: Modernism and Masculinism" and Elaine Showalter's "Representing Ophelia: Women, Madness, and the Responsibilities of Feminist Criticism”. In the latter two 
academic essays especially Elaine Showalter's, we can obvious feel that feminist critics casted an eye over the female protagonist in the literature works from female's perspective to overturn the traditional, more specifically, the male depiction about the female roles. We can conclude from "Tradition and the Female Talent: Modernism and Masculinism” that men always use binary thought to value and depict women. In patriarchal tradition, angel and monster are the stereotyped female images. Women are always either passive, submissive and selfless or mad or hysteria.

In "Representing Ophelia: Women, Madness, and the Responsibilities of Feminist Criticism", Showalter did a good job to reveal men's attitude of prejudice and despise towards women as well as their "men-centered" view through deconstructing Ophelia, the classical female role in Shakespeare's Hamlet. Feminist critic Lee Edwards concludes: "We can imagine Hamlet's story without Ophelia, but Ophelia literally has no story without Hamlet” (Showalter, 1986, p. 78). Showalter also said: "In comparison to Hamlet, Ophelia is certainly a creature of lack" (Showalter, 1986, p. 78). Ophelia, about whom Showalter discussed is after all depicted by Shakespeare, a man. "Freud suggested that man had an entirely different self within, anthropology and archaeology revealed that patriarchal society was not necessarily the only (not to say the best) form of social organization for humanity" (Zhu, 2001, p. 229). Thus, Fiona and Marian of "The Bear Came Over the Mountain" which is written by the female writer are peculiar cases to catch our attention to analyze.

In actuality, "The Bear Came Over the Mountain" is a distinctive gynotext which means feminist discourse for female identity but also a special case in that Munro depicts the two female roles mainly from the hero Grant's perspective. "It was more that readers assumed a woman could 'only' write about herself, given the confinement of her life and, by extension, of her mental processes” (Parkin-Gounelas, 1991, p. 24). Since more people hold that bias about female writers while Munro did a success in depicting Grant, I very appreciate her and strongly believe that she organizing the story in this way is out of purpose to present a "lack" of the female and the constrained self-voice of the female. Understanding Munro's writing purpose in such a way enables us to eradicate the stereotyped critics from a man's standpoint and reevaluate the two female roles in a deconstructive way according to different readers' different experience and analysis. Woolf exposed that "language refused to pinned down to an underlying essential meaning” (Zhu, 2001, p. 235). Jacques Derrida also expressed "language is structured as an endless deferral of meaning, and any search for an essential, absolutely stable meaning must therefore be considered metaphysical” (Zhu, 2001, p. 235).

If I can be allowed to use one word to define Fiona this character, I'd like to choose "silence". Nearly all Fiona's behaviors and the descriptions about her are expressed from Grant's perspective in an indirect way. Grant is just like Fiona's spokesman from whom readers get the impression about Fiona's beautiful appearance. "She looked just like herself on this day — direct and vague as in fact she was, sweet and ironic” (Munro, 1999). Besides, in the story, it's never be clear mentioned that Fiona's thinking about going to the institution Meadowlake and readers only find the contradiction in Grant's inner heart: "If she could remember that, so vividly and correctly, could there really be so much the matter with her? It was all he could do not to turn around and drive home” (Munro, 1999). When Grant was a college professor, there were many gossips about his relationship with the girl students, which annoyed Fiona. Then he also made decision of quitting the job and worked on the house with Fiona in the name of promising Fiona a new life. In fact, Grant did things only out of his own feelings: 
Many times he had catered to a woman's pride, to her fragility, by offering more affection — or a rougher passionthan anything he really felt. All so that he could now find himself accused of wounding and exploiting and destorying self-esteem. And of deceiving Fiona—as, of course, he had. (Munro, 1999)

Later Fiona establishes a close relationship with Aubrey in the institution about which Grant feels a threat but finally accepts. Even when Fiona deteriorates after Aubrey is taken back home by his wife Marian, Grant decides to ask for Marian to send Aubrey back to institution with a date. From these processes, readers only know the complicated mental activities of Grant instead of hearing what Fiona really wants to say. Maybe most people are even moved by Grant's consideration and affection towards Fiona through his deeds and emotional changes, but what I'm concerned is the silence of Fiona because Fiona can't utter her real own voice, and more precisely speaking, her voice is constrained and substituted by Grant with his voice and thought. Let us imagine: If Fiona is a normal woman without getting Alzheimer's disease, will she abandon her love with Grant but developing a romantic bond with a total stranger? If Fiona is like that she was, can she say "yes” to allow Grant to make a deal with Marian in the name of improving her health quality? In a word, all what Grant does is just out of his own selfish thoughts by depriving Fiona's right to speak out her self-voice. So how can we think what Grant does is a noble one?

As for the other female protagonist Marian, I think she deserves more emphasis and careful reconstruction. At the first reading and impression about Marian this character, I believe many readers have the same dislike and even hate as me. Marian is a plain-looking old woman, far from Fiona's beauty and grace. She is also cold, tough, and merciless with her unhesitating reject to Grant's request of sending Aubrey back to the institution. But later she seems to change her mind by sending Grant the telephone message of inviting him to join a party with her. For readers, after the first reading, Marian is also a crafty woman, knowing how to threaten Grant with a date. However, after the careful re-reading and analysis of the detailed information, I dare not insist on that Marian is just an evil woman who only takes use of others.

It's Marian's some words that makes me reconstruct this role and change my negative view about her. Just take Marian's one reply into consideration, “But I don't have much choice. I don't have the money to put him in there unless I sell the house” (Munro, 1999), we can sense more or less bitterness and misery about Marian’s situation. She is just an old woman, taking care of his husband alone although the old couple has a son and the wife of their son. When Grant asks Marian whether her son and his wife are busy, Marian answers ironically: "They weren't too busy to go to Hawaii last winter. You could understand it if we had somebody else in the family, close at hand. But he’s the only one” (Munro, 1999). Even her own son doesn't want to lend her a hand, we can know what a hardship Marian is suffering alone. Just because of the bitter reality, Marian forms her toughness, coldness, and sense of reality towards life on the one hand, and gradually loses her selfness with the handling of the life of hardships and bitterness on the other hand.

In fact, toughness, coldness, being determined seen from Marian is what the man usually has. This kind of expression conforms to what Virginia Woolf called "androgynous vision" which means "full balance and command of an emotional range that include male and female elements" (Zhu, 2001, p. 238). Compared with the stereotyped female images, Marian represents a balance and mix of female and male characteristics. Her female inner voice is actually deep constrained. The living bitterness enforces her to cover her female weakness and fragility with the support of male characteristics. Munro's writing and depiction “to alter the stereotyped visions 
of women, female characters are depicted as strong, active heroes rather than passive sidekicks to the great male protagonist” (Green \& LeBihan, 1996, p. 235).

When taking care of the sick Aubrey, Marian instead is like a man to make any decision about this family and Aubrey. So she has the absolute and determined decision and right to talk and negotiate with Grant. She adopts authorized attitude to evaluate Grant's request and undoubtedly rejects it by saying that: "I can't afford to risk it. I don't want him upset and carrying on. I've got my hands full with him as it is. I don't have any help. It's just me here. I'm it” (Munro, 1999, p. 15).

In spite of Marian's strong male characteristics, she is a woman after all and more specifically a lonely woman. She has a disabled husband without children living with her. Her female desires and drives are deeply constrained to release. "For Woolf, as for Freud, unconscious drives and desires constantly exert a pressure on our conscious thoughts and actions” (Zhu, 2001, p. 234). At that time, the appearance of Grant and their similar situations bring Marian a kind of subtle emotional ups and downs. Her carefully and unconsciously constrained female characteristics are lit up. So she sends the invitation to Grant for a date. We can say that Marian must be crazy and abnormal with her immoral deeds, but we also sense a kind of nervousness and excitement in the telephone message from her: "A tremor of nerves there, an affected nonchalance, a hurry to get through and a reluctance to let go" (Munro, 1999, p. 17). Meanwhile, Marian is with the hope of Grant’s reply because "Just the realization that he was a possibility, a man on his own. More or less on his own. A possibility that she might as well try to follow up” (Munro, 1999, p. 17). Marian suddenly changing her mind and performing so positively fully improve that in her inner heart, there is such a constrained self-voice which is eager to release.

Reviewing the above original and attractive analysis and reconstruction, I certainly believe that readers can be convinced by the other but brand new perspective to begin to understand the two female roles in "The Bear Came Over the Mountain” with the use of some methods of feminist criticism. Feminist criticism is a critic method not only helping us to re-evaluate the female writers and their works but also doing the readers a favor to better and comprehensively understand the female characters depicted by the female writers. Such as the two female roles Fiona and Marian who catch little attention of the readers actually can become the protagonists for critics with their sharing common points and typical female characteristic that is both of their lose, their self-voice of the female is constrained against the man-centered point of view. In fact, the two female roles have rich values for readers to deeply deconstruct and reconstruct. So releasing their constrained voices is an urgent and valuable work for each reader and critic.

\section{References}

Green, K., \& LeBihan, J. (1996). Critical theory and practice: A coursebook. London: Routledge.

Gilbert, S. M., \& Gubar, S. (1994). Tradition and the female talent: Modernism and masculinism. New York : Garland Publishing. Munro, A. (1999). The bear came over the mountain. Retrieved from https://www.newyorker.com/magazine/1999/12/27/the-bear-came-over-the-mountain/amp Parkin-Gounelas, R. (1991). Fictions of the female self. London: Macmillan Academic and Professional Ltd.

Showalter, E. (1986). Representing Ophelia: Women, madness, and the responsibilities of feminist criticism. Shakespeare and the Question of Theory. Ed. Patricia Parker and Geoffrey Hartman. 1985. 77-94. Rpt. in Shakespeare Criticism. Ed. Dana Ramel Barnes. Vol. 35. Detroit: Gale Research, 1997. Literature Resources from Gale. Web. 7 Nov. 2012.

Woolf, V. (1929). Shakespeare’s sister: From a room of one’s own. England: Hogarth Press.

Zhu, G. (2001). Twentieth century western critical theories. Shanghai: Shanghai Foreign Language Education Press. 